\title{
The Relationship between Modification of Food Presentation and Changes in Appetite of Toddler Children at Puskesmas Mojo Surabaya
}

\author{
Refida Fitria Anggraini1, Aries Chandra A², Latifiyan N.A³, Oski Illiandri ${ }^{4}$ \\ 1,33)Fakultas Ilmu Kesehatan, Universitas Muhammadyah Surabaya \\ 4)Fakultas Kedokteran, Universitas Lambung Mangkurat Banjarmasin
}

\begin{abstract}
Background: Modification of food presentation is one way to attract toddlers to increase their appetite with attractive colors or cute shapes to increase the child's appetite. Modification of food presentation can also affect appetite changes in children under five, so it takes a unique and exciting food creation that can be an attraction/pleasure for children under five to increase appetite. Children's stability under five depends a lot on their parents or caregivers because the parents must be the main scourge / main factor in increasing the child's appetite. So, it can be said that the development of children under five is very dependent on how their parents manage their child's food-providing a variety of foods, especially vegetables, which children usually do not like so that they become liked by them. There are many things or ways to attract toddlers to like vegetables, namely by adding side dishes that have been mixed with vegetables and rice that can be cooked and mixed with coloring from the vegetables themselves.
\end{abstract}

Objective: To explore the relationship between food presentation modification and appetite changes for children under five at Puskesmas Mojo Surabaya.

Method: Analytical Cross-Sectional Observational Research Design

Result: Most of the modification of food presentation for children under five at Puskesmas Mojo Surabaya received it well. Changes in appetite for children under five at Puskesmas Mojo Surabaya are mostly changes in appetite.

Conclusion: There is a relationship between modification of food presentation and appetite changes for children under five at Puskesmas Mojo Surabaya.

Keywords: Appetite; Food Presentation; Toddler

Correspondence: anandhita.ners@um-surabaya.ac.id

\section{PENDAHULUAN}

Nafsu makan adalah suatu masalah yang komplek terjadi pada setiap balita dan anak-anak. Namun hal ini sering sekali dan cenderung sekali dialami pada balita dan anak-anak yang sedang mengalami masa pertumbuhan. Agar masa pertumbuhannya tidak terganggu dan tidak mudah terserang penyakit. Nafsu makan adalah masalah yang paling umum di masyarakat awam ketika keadaan yang terjadi tidak dapat ditangani. Nafsu makan adalah keinginan untuk makan makanan, merasa lapar dan meyukai makanan tertentu. Pertumbuhan dan perkembangan balita merupakan suatu hal yang perlu mendapat perhatian besar. Hal ini karena pada masa balita merupakan masa dengan pertumbuhan yang sangat pesat dan kritis, biasanya 
dikenal dengan istilah golden age atau masa emas. Anak usia balita akan mengalami pertumbuhan dan perkembangan terutama pada fungsi bahasa, kognitif, dan emosi. Untuk menunjang pertumbuhan dan perkembangan tersebut, asupan nutrisi dari makanan merupakan salah satu faktor yang berperan penting bagi seorang anak (Kumala, 2005).

Menurut sensus yang dilakukan World Health Organization (WHO) tahun 2012 sebanyak 84\% kasus kekurangan gizi anak usia dibawah lima tahun (balita) terjadi di Asia dan Afrika. Sedangkan di Indonesia tahun 2012 terdapat sekitar 53\% anak di bawah usia 5 tahun menderita gizi buruk disebabkan oleh kurangnya makanan untuk mencukupi kebutuhan gizi sehari-hari (Depkes, 2012). Berdasarkan Laporan Riset Kesehatan Dasar (RISKESDA) (Trihono 2013), kecenderungan prevalensi status gizi anak balita $\mathrm{Di}$ Propinsi Jawa Timur tahun 2010 diketahui terdapat 2,4 juta balita dan 15\% diantaranya mengalami masalah sulit makan. Di Kabupaten Ponorogo tahun 2010 terdapat 1300 balita kurang gizi yang tersebar di seluruh wilayah Kecamatan. Dari total tersebut sebesar 700 balita mengalami sulit makan. Untuk wilayah Ponorogo kota terdapat 146 balita mengalami sulit makan (Aisyah, 2011). Berdasarkan PSG (Pemantauan Status Gizi) tahun 2012 untuk Provinsi Jawa Timur, angka gizi buruk pada balita berdasarkan BB/U (Berat Badan Dibandingkan Dengan Umur) sangat buruk sebesar 2,35\% (Dinas Kesehatan Provinsi Jawa Timur, 2013). Sedangkan dari hasil study pendahuluan di Puskesmas Mojo Surabaya penurunan nafsu makan pada anak balita tinggi di akhir periode ini mencapai sebanyak $20 \%$ di tahun 2015.

Menurut Fathonah (2005), Nafsu makan sangat berhubungan dengan status gizi balita karena pada anak balita mempunyai nafsu makan yang berubahubah tergantung pada kondisi makanan tersebut. Kondisi makanan yang dimaksud adalah yang dapat menarik anak balita tersebut untuk gemar mengkonsumsi makanan yang berbagai macam, terutama makanan yang dapat mempengaruhi tumbuh kembang anak balita tersebut. Nafsu makan menurun juga dapat memperhambat status kesehatan anak balita. Nafsu makan dapat dilihat dari asupan makanan kurang dari yang dibutuhkan akan menyebabkan tubuh menjadi kurus dan rentan terhadap penyakit. Nafsu makan pada anak balita memang sering berubah-ubah tergantung dari kondisi orang tua yang menyajikan makanan anak balita tersebut (Fathonah, 2005).

Modifikasi penyajian makanan adalah salah satu cara untuk menarik anak balita agar dapat meningkatkan nafsu makan yang memiliki warna semenarik mungkin atau bentuk-bentuk yang lucu untuk dapat meningkatkan nafsu makan pada anak itu sendiri. Modifikasi penyajian makanan juga dapat mempengaruhi perubahan nafsu makan pada anak balita, Maka dibutuhkan kreasi makanan yang unik dan semenarik mungkin yang dapat menjadi daya tarik/kesenangan sendiri bagi anak balita untuk peningkatan nafsu makan. Mapkanan anak balita banyak tergantung pada orang tua atau pengasuhnya, karena hal itu orang tualah yang harus menjadi momok utama/faktor utama untuk 
meningkatkan nafsu makan pada anak itu sendiri. Jadi, dapat dikatakan bahwa tumbuh kembang anak balita sangat tergantung pada bagaimana orang tuanya mengatur makanan anaknya. (Irianto, 2006).

Pemberian beragam makanan terutama sayuran yang biasanya kurang disukai oleh anak supaya menjadi disukai oleh anak. Banyak hal atau cara untuk menarik anak balita agar dapat menyukai sayuran. yaitu dengan menambah lauk pauk yang sudah dicampur dengan sayuran dan juga nasi yang dapat dimasak dan dicampur dengan pewarna dari sayuran itu sendiri (Mukono, 2006). Berdasarkan masalah di atas peneliti ingin melakukan penelitian tentang "Hubungan Modifikasi Penyajian Makanan Dengan Perubahan Nafsu Makan Anak Balita di Puskesmas Mojo Surabaya".

\section{METODE PENELITIAN}

\section{Desain Penelitian}

Desain penelitian dalam penelitian ini menggunakan desain penelitian analitik Cross Sectional yang menekankan pada waktu pengukuran observasi data variabel independen dan variabel dependen hanya satu kali, pada satu saat. Pada jenis ini variabel independen dan dependen dinilai secara simultan pada satu saat, jika tidak ada follow up. Tentunya tidak semua subjek penelitian harus diobservasi pada hari atau waktu yang sama, akan tetapi baik variabel indepeden maupun variabel dependen dinilai hanya satu kali saja. Dengan studi ini akan diperoleh prevalensi atau efek suatu fenomena (variabel dependen) dihubungkan dengan penyebab (variabel independen) (Nursalam, 2008).

\section{Populasi, Sampel, dan Sampling}

Populasi dalam penelitian adalah seluruh ibu yang memiliki anak balita di Posyandu yang mengalami penurunan nafsu makan yaitu sebanyak 75 orang sesuai dengan data yang didapat pada studi pendahuluan di Puskesmas Mojo kelurahan gubeng kecamatan gubeng. Teknik sampling adalah proses menyeleksi porsi dari populasi untuk mewakili populasi. Teknik sampling merupakan cara-cara yang ditempuh dalam pengambilan sampel, agar memperoleh sampel yang benar-benar sesuai dengan keseluruhan subjek penelitian (Nursalam, 2008), probability sampling dengan jenis pengambilan sampel menggunakan cluster sampling adalah teknik pengambilan sampel yang dilakukan dengan cara acak tanpa memperhatikan strata yang ada dalam anggota populasi. (Hidayat, 2010). Sampel adalah sebagian yang diambil dari keseluruhan obyek yang diteliti dan dianggap mewakili seluruh populasi (Notoatmodjo, 2005). Besar sampel pada penelitiian adalah 63 responden.

\section{Variabel Penelitian}

Variabel adalah suatu ukuran atau cirri yang dimiliki oleh anggota suatu kelompok yang berbeda dengan yang dimiliki oleh kelompok tersebut (Nursalam, 2008). Pada penelitian dibedakan menjadi dua variabel, yaitu variabel independen dan variabel dependen. Variabel independen pada penelitian ini yaitu modifikasi penyajian makanan. Sedangkan variabel 
dependen pada penelitian ini yaitu perubahan nafsu makan.

\section{Waktu dan Lokasi Penelitian}

Lokasi penelitian dilakukan di Puskesmas Mojo kelurahan Mojo kecamatan Gubeng yang dilaksanakan pada tanggal 3 agustus 2016.

\section{Pengumpulan dan Analisis Data}

Dalam penelitian ini instrument yang digunakan untuk pengumpulan data adalah berupa lembar kuisioner penampilan makanan dan kuisioner perubahan nafsu makan untuk mengukur berat badan. Kuisioner juga telah dilakukan uji validitas dan reabilitas oleh peneliti terhadap 25 responden, dari 56 pertanyaan kuisioner mempunyai nilai $\mathrm{r}$ tabel $>0,514$, dan nilai cronbach's alpha yang didapatkan adalah 0,752. Sehingga dapat disimpulkan bahwa butir pertanyaan dalam kuisioner valid dan realiabel.

Sebelum pelaksanaan penelitian, peneliti berkunjung ke rumah Ibu Kader Posyandu Balita menjelaskan maksud dan tujuan pelaksanaan penelitian. Mengikuti kegiatan posyandu satu bulan terakhir dan diberikan izin untuk observasi kerumah Ibu yang mempunyai anak balita yang mempunyai criteria sesuai dengan judul penelitian tersebut.

Data yang terkumpul dilakukan koding. Setiap jawaban yang telah ada pada lembar kuisioner dengan pertanyaan diberi kode "Ya" = 1 dan "Tidak" $=0$. Pada pernyataan penampilan makanan diberikan kode jika "Selalu" $=4$, "Sering"= 3, "Jarang"= 2, "Tidak Pernah"= 1.
Pada pernyataan perilaku makan anak diberikan kode jika "Selalu"= 5, "Sering"= 4, "Kadangkadang" $=3$, "Tarang" $=2$, "Tidak Pernah" $=1$. Kemudian dilakukan skoring data berdasarkan prosentase (Dewi, 2010). Baik= bila didapatkan hasil 76-100\%; Cukup= bila didapatkan hasil 56$75 \%$, Kurang $=$ bila didapatkan hasil $<56 \%$; Kategori Perilaku Nafsu Makan Anak: Responsif terhadap Makanan $(\mathrm{RM})=1$, Lebih Emosional terhadap Makan $(L E M)=2$, Menikmati Makanan $(M M)=3$, Keinginan untuk Minum $(K M)=4$, Responsif terhadap rasa Kenyang $(\mathrm{RK})=5$, Lambat ketika Makan $(\mathrm{LM})=6$, Kurang Emosional terhadap Makan (KEM) $=7$, dan Rewel Terhadap Makanan $\quad($ RTM $)=8$; Cara interpretasikan data berdasarkan prosentase (Dewi, 2010): Baik = bila didapatkan hasil $76-100 \%$, Cukup $=$ bila didapatkan hasil 56-75\%, dan Kurang= bila didapatkan hasil $<56 \%$.

Data yang sudah dikumpulkan kemudian dianalisis menggunakan chi-square (Hidayat, 2010) untuk mengetahui variabel dependen tingkat kemaknaan $\alpha=0,05$ artinya bila nilai $\mathrm{p}$ $<\alpha$ maka H0 ditolak, berarti ada hubungan modifikasi makanan penyajian makanan dengan perubahan nafsu makan anak balita di Puskesmas Mojo Surabaya.

\section{HASIL PENELITIAN}

\section{Gambaran Umum Lokasi Penelitian}

Penelitian dilakukan di wilayah yang Puskesmas Mojo terletak di kecamatan Gubeng Provinsi Jawa Timur. Puskesmas Mojo dikepalai oleh dr. Nurul Atfianah. Dengan fasilitas ada poli anak, poli kandungan, 
poli KIA \& KB. Adapun batas wilayah Puskesmas Mojo dapat diuraikan sebagai berikut :

1. Sebelah utara berbatasan dengan rumah penduduk

2. Sebelah selatan berbatasan dengan rumah penduduk

3. Sebelah barat berbatasan dengan rumah penduduk

4. Sebelah timur berbatasan dengan rumah penduduk
Mayoritas penduduk di Kecamatan Gubeng beragama Islam. Penduduk di Kecamatan Gubeng mayoritas suku Jawa, tetapi Surabaya juga menjadi tempat tinggal berbagai suku di Indonesia, termasuk Madura, Tionghoa, Arab, dan sisanya merupakan suku bangsa lain atau warga asing.

\section{Karakteristik Demografi Responden}

Jenis Kelamin Balita

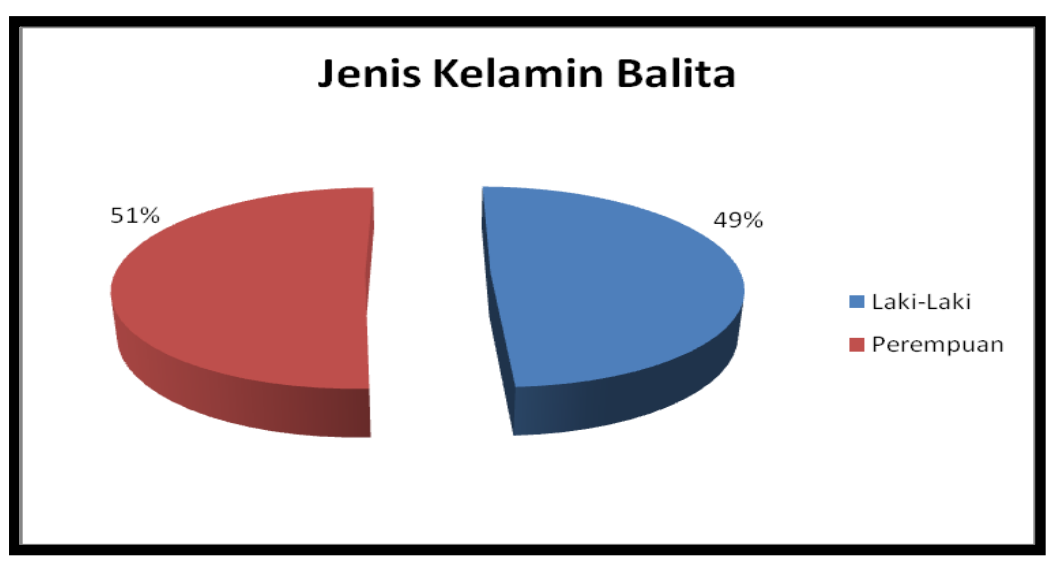

Gambar 4.1 Distribusi Responden Berdasarkan Jenis Kelamin Balita Di Puskesmas Mojo Pada 3 Agustus 2016 .

Berdasarakan gambar 4.1 menunjukkan bahwa jenis kelamin balita yaitu sebagian besar Perempuan sebesar $51 \%$ sebanyak 32 responden dan sebagian kecil Laki-laki sebesar $49 \%$ sebanyak 31 responden.

Gambar 4.2 menunjukkan bahwa jenjang pendidikan responden yaitu sebagian besar berpendidikan SMA sebesar 51\% sebanyak 32 responden dan sebagian kecil berpendidikan SD sebesar 16\% sebanyak 10 responden serta berpendidikan SMP sebesar 16\% sebanyak 10 responden.
Sedangkan gambar 4.3 menunjukkan bahwa pekerjaan responden sebagian besar sebagai ibu rumah tangga sebesar 60\% sebanyak 38 responden dan sebagian kecil sebagai PNS 1\% sebanyak 1 responden, perawat 2\% sebanyak 1 responden, serta apotek $2 \%$ sebanyak 1 responden.

Berdasarkan gambar 4.4 menunjukkan bahwa pendapatan responden yaitu sebagian besar $>$ 1 juta sebesar 44\% sebanyak 28 responden dan sebagian kecil $<800$ ribu sebesar 21\% sebanyak 13 responden. 
Jenjang Pendidikan Ibu

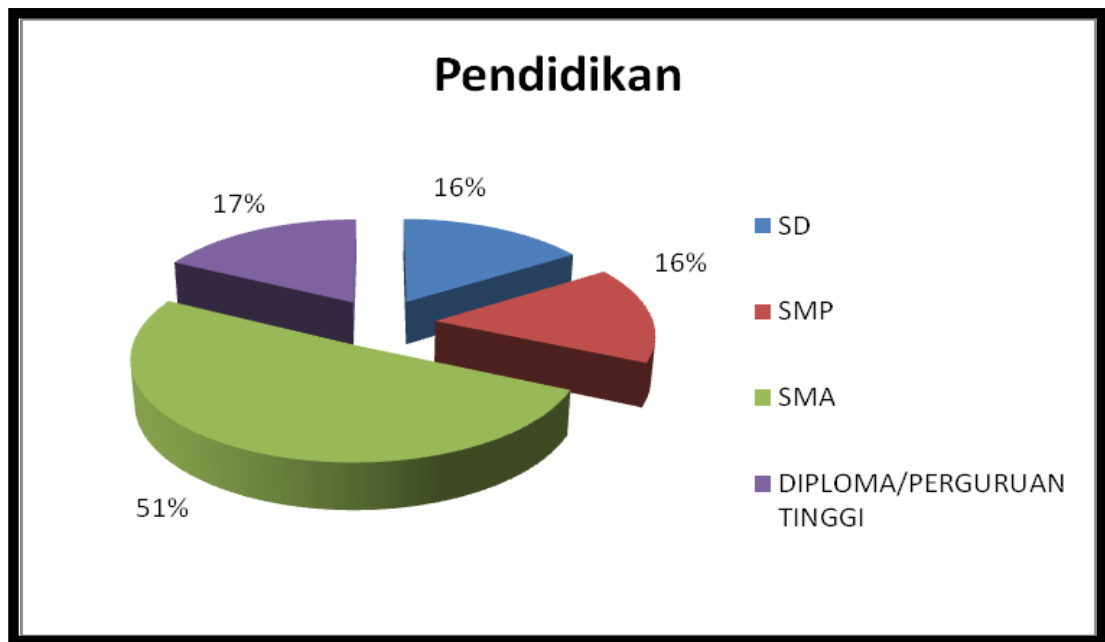

Gambar 4.2 Distribusi Responden Berdasarkan Jenjang Pendidkan Di Puskesmas Mojo Pada 3 Agustus 2016.

\section{Pekerjaan Ibu}

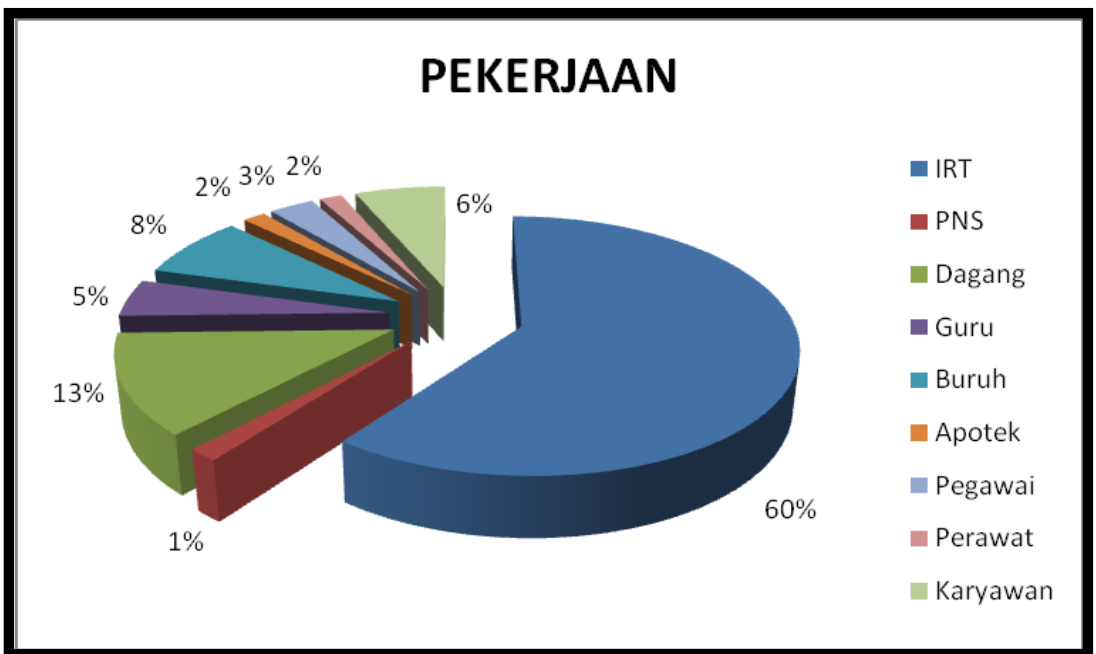

Gambar 4.3 Distribusi Responden Berdasarkan Pekerjaan Di Puskesmas Mojo Pada 3 Agustus 2016.

\section{Pendapatan Orang Tua}

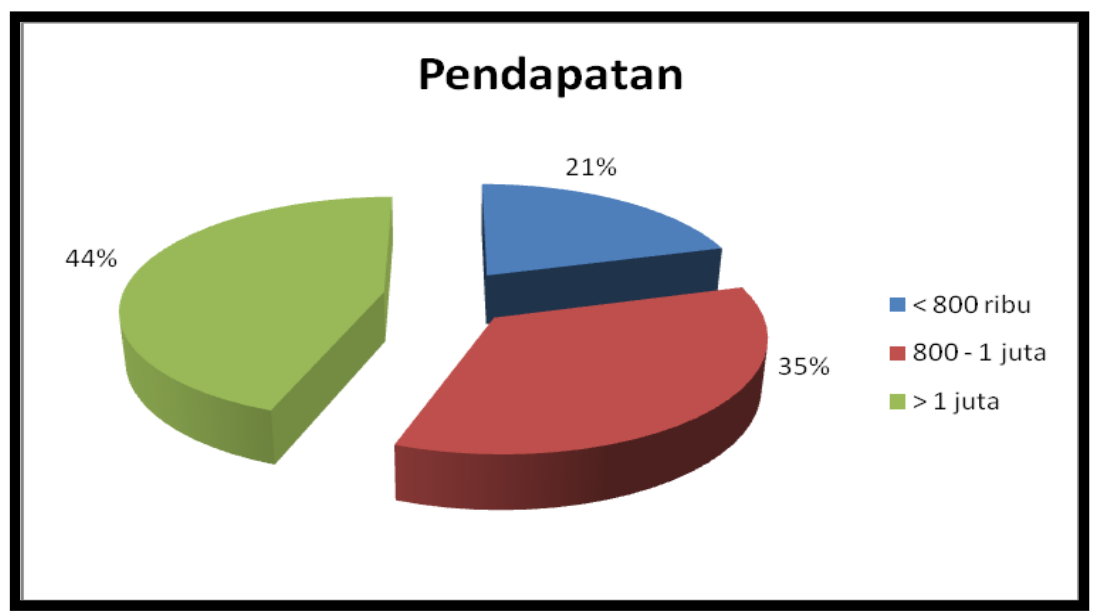

Gambar 4.4 Distribusi Responden Berdasarkan Pendapatan Di Puskesmas Mojo Pada 3 Agutus 2016. 


\section{Penyuluhan Tentang Gizi Balita}

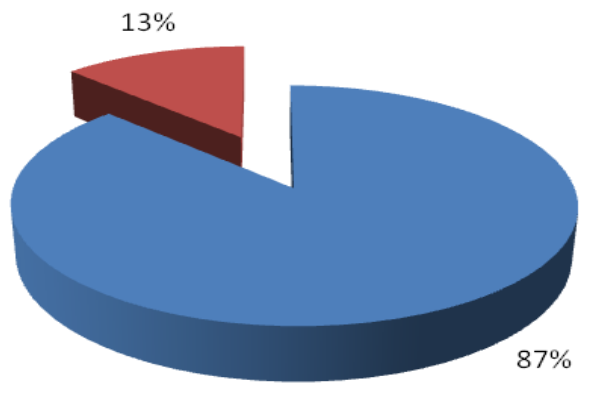

- Pernah

- Tidak Pernah

Gambar 4.5 Distribusi Responden Berdasarkan Penyuluhan Tentang Gizi Balita Di Puskesmas Mojo Pada 3 Agutus 2016.

Berdasarkan gambar 4.5 menunjukkan bahwa responden yang mengikuti penyuluhan tentang gizi balita yaitu sebagian besar pernah

\section{Berat Badan Balita}

\section{Berat Badan}

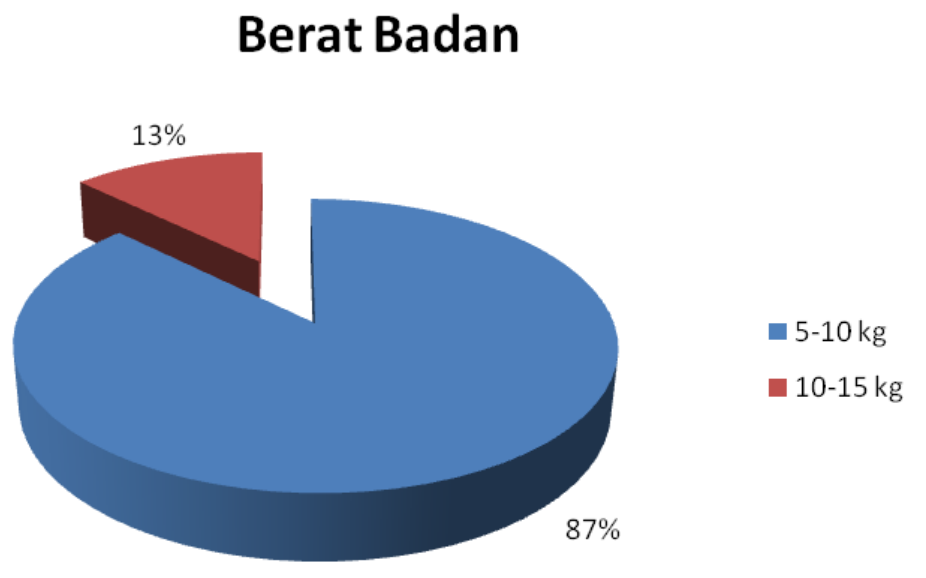

mengikuti sebesar $87 \%$ sebanyak 55 responden dan sebagian kecil tidak pernah mengikuti sebesar $13 \%$ sebanyak 8 responden.

Gambar 4.6 Distribusi Responden Berdasarkan Berat Badan Balita Di Puskesmas Mojo Pada 3 Agutus 2016.

Berdasarkan gambar 4.6 menunjukkan bahwa responden yang memiliki berat badan $5-10 \mathrm{~kg}$ sebesar $87 \%$ sebanyak 55 responden dan responden yang memiliki berat badan $10-15 \mathrm{~kg}$ sebesar 13\% sebanyak 8 responden.

\section{Identifikasi Modifikasi Penyajian Makanan Pada Anak Balita}

Pada tabel 4.1 diatas diketahui sebagian besar anak balita di Puskesmas Mojo Surabaya yang 
menerima modifikasi penyajian makanan baik sebanyak 33 orang (52\%), modifikasi penyajian makanan kurang sebanyak 17 orang $(27 \%)$, dan modifikasi penyajian makanan cukup sebanyak 13 orang $(21 \%)$.

Tabel 4.1 Distribusi Frekuensi Modifikasi Penyajian Makanan Pada Anak Balita di Pukesmas Mojo Bulan Agustus 2016

\begin{tabular}{lcc}
\hline Modifikasi Penyajian Makanan & Frekuensi (f) & Persentase (\%) \\
\hline Baik & 33 & 52 \\
Cukup & 13 & 21 \\
Kurang & 17 & 27 \\
\hline Jumlah & 63 & 100 \\
\hline
\end{tabular}

\section{Identifikasi Perilaku Nafsu Makan Pada Anak Balita}

Tabel 4.2 Distribusi Frekuensi Perilaku Nafsu Makan Pada Anak Balita di Puskesmas Mojo Bulan Agustus 2016

\begin{tabular}{lcc}
\hline Perilaku Nafsu Makan & Frekuensi (f) & Persentase (\%) \\
\hline Baik & 26 & 41 \\
Cukup & 29 & 46 \\
Kurang & 8 & 13 \\
\hline Jumlah & 63 & 100 \\
\hline
\end{tabular}

Pada tabel 4.2 diatas diketahui sebagian besar anak balita di Puskesmas Mojo Surabaya yang mengalami perilaku nafsu makan cukup sebanyak 29 orang (46\%), perilaku nafsu makan kurang sebanyak baik 26 orang (41\%), dan perilaku nafsu makan kurang sebanyak 8 orang $(13 \%)$.

Hubungan Modifikasi Penyajian Makanan dengan Perubahan Nafsu Makan Anak Balita di Puskesmas Mojo Surabaya

Tabel 4.3 Tabel Hubungan Modifikasi Penyajian Makanan dengan Perubahan Nafsu Makan Anak Balita di Puskesmas Mojo Surabaya Bulan Agustus 2016

\begin{tabular}{lcccccccc}
\hline Modifikasi & \multicolumn{4}{c}{ Perubahan Nafsu Makan } & \multicolumn{3}{c}{ Total } \\
\cline { 2 - 9 } Penyajian & Baik & $\%$ & Cukup & $\%$ & Kurang & $\%$ & N & $\%$ \\
\hline Bakanan & 17 & 27 & 16 & 25,4 & 0 & 0 & 33 & 52,4 \\
Cukup & 3 & 4,8 & 7 & 11,1 & 3 & 4,8 & 13 & 20,6 \\
Kurang & 6 & 9,5 & 6 & 9,5 & 5 & 7,9 & 17 & 27 \\
\hline Total & 26 & 41,3 & 29 & 46 & 8 & 12,7 & 63 & 100 \\
\hline
\end{tabular}

Uji Chi-square $p=0,020<\alpha=0,05$

Tabel 4.3 diatas diketahui dari 33 balita di Puskesmas Mojo yang menerima modifikasi penyajian makanan baik sebagian besar memiliki perilaku nafsu makan yang baik yaitu 17 balita (27\%), dari 13 balita yang menerima modifikasi penyajian makanan cukup sebagian 
besar memiliki perilaku nafsu makan cukup yaitu 7 balita (11,1\%), dan dari 17 balita yang menerima modifikasi penyajian makanan baik dan cukup yaitu 6 balita $(9,5 \%)$.

Berdasarkan analisis untuk mngetahui hubungan modifikasi penyajian makanan dengan perubahan nafsu makan pada balita menggunakan uji chi-square program SPSS windows versi 21,00 didapatkan hasil sebesar 0,020 dengan tingkat signifikan $p=(0,000)<$ $\alpha=0,05$ sehingga $H_{1}$ diterima artinya terdapat hubungan antara modifikasi penyajian makanan dengan perubahan nafsu makan pada balita di Puskesmas Mojo Surabaya.

\section{PEMBAHASAN}

\section{Identifikasi Modifikasi Penyajian Makanan}

\section{Pada Anak Balita di Puskesmas Mojo}

\section{Surabaya}

Berdasarkan tabel 4.1 diketahui bahwa anak balita di Puskesmas Mojo Surabaya yang menerima modifikasi penyajian makanan baik sebanyak 33 orang (52\%), modifikasi penyajian makanan kurang sebanyak 17 orang (27\%), dan modifikasi penyajian makanan cukup sebanyak 13 orang (21\%). Dari hasil tersebut diketahui sebagian besar anak balita yang menerima modifikasi penyajian makanan baik yaitu sebanyak 33 orang dari 63 responden (52\%).

Menurut penelitian sebelumnya Gumala (2010), penyajian makanan merupakan salah satu faktor yang tidak kalah pentingnya karena tanpa memperhatikan cara penyajian makanan, maka makanan akan tampak tidak menarik meskipun telah diperhatikan cara pengolahan yang sebaik-baiknya.

Menurut Moehyi (2007), Penyajian Makanan yaitu penempatan makanan yang sudah siap dimakan dalam tempat yang tepat. Makanan yang akan dihidangkan harus bervariasi dan disajikan semenarik mungkin baik dari warna maupun bentuknya, sehingga anak akan merasa senang dan tertarik untuk menikmati hidangan yang disediakan. Makanan yang dihidangkan untuk anak di samping harus memperhatikan kandungan gizi juga harus fasilitas lain.

Faktor yang dapat mempengaruhi modifikasi penyajian makanan menurut Moehyi (2008) adalah warna makanan, tekstur makanan, bentuk makanan, pemilihan alat yang digunakan, porsi makanan, kondisi makanan yang disajikan, jadwal makanan, penghias makanan. Berdasarkan penelitian Nurhayati, dkk (2008) di RS Bhakti Wira Tamtama Semarang menyatakan bahwa $35 \%$ pasien hampir seluruhnya menyatakan penampilan makanan menarik. Berdasarkan penelitian Gumala (2010) di RSUD Karangasem, menyatakan bahwa penyajian makanan sudah cukup baik dengan 40 sampel (95,2\%).

Modifikasi penyajian makanan yang baik adalah makanan yang disajikan dengan cara memakai warna alami untuk menarik selera makan anak agar dapat meningkatkan nafsu makan, modifikasi penyajian makanan juga dapat menjadi kegemaran anak-anak. Hal ini disebabkan karena setiap anak mempunyai 
nafsu makan yang berbeda-beda sehingga susah untuk menilai penampilan makanan. Modifikasi penyajian makanan sebaiknya digunakan setiap hari agar anak tidak cepat merasa bosan dengan makanan yang tidak ada perubahan. Orang tua juga harus lebih banyak belajar mengenai modifikasi penyajian makanan, agar lebih memudahkan orang tua dalam membuat menu makanan terbaru yang belum pernah dicoba oleh anak-anak. Modifikasi penyajian makanan yang dilakukan ibu sangat dipengaruhi oleh tingkat pendidikan ibu, semakin tinggi tingkat pendidikan ibu maka semakin tinggi pula pengetahuan tentang cara melakukan modifikasi. Pekerjaan ibu juga dapat mempengaruhi modifikasi penyajian makanan karena pekerjaan ibu yang menjadi ibu rumah tangga lebih besar pengaruhnya untuk pertumbuhan anak balita.

Dengan cara modifikasi penyajian makanan yang dilakukan setiap hari dapat membantu anak-anak untuk meningkatkan nafsu makan mereka yang sering mengalami perubahan, dari nafsu makan yang tinggi menjadi nafsu makan yang rendah.

Pada responden mayoritas ibu melakukan modifikasi penyajian makanan dalam hal membuat bentuk-bentuk, menggunakan warna alami yang terbuat dari sayuran, menggunakan alat makan yang aman bagi balita, mengetahui porsi makan anak balita, mengatur jadwal makan, mengetahui tekstur dan mengetahui kondisi makanan yang baik bagi pertumbuhan balita.

\section{Identifikasi Perilaku Nafsu Makan Pada Anak Balita di Puskesmas Mojo Surabaya}

Berdasarkan hasil penelitian menunjukkan bahwa anak balita di Puskesmas Mojo Surabaya yang perilaku nafsu makan cukup sebanyak 29 dari 63 responden (46\%), perilaku nafsu makan baik sebanyak 26 dari 63 responden (41\%), dan perilaku nafsu makan kurang sebanyak 8 dari 63 responden $(13 \%)$. Dari data tersebut diketahui mayoritas balita mengalami nafsu makan cukup sebanyak 29 orang (46\%) dari 63 responden.

Menurut penelitian sebelumnya Sudibyo \& Mulyani (2009), kelompok usia terbanyak mengalami kesulitan makan adalah usia 1-5 tahun (58\%), dengan jenis kelamin terbanyak laki-laki (54\%). Sedangkan menurut penelitian Aristiana, dkk (2015), bahwa anak yang mengalami perilaku kesulitan makan sebanyak $(35,4 \%)$, terdapat $(21,5 \%)$ anak menutup mulut rapat-rapat saat diberikan makanan, $(49,4 \%)$ tidak tertarik mencoba makanan baru, $(15,2 \%)$ anak membuang makanan yang diberikan.

Menurut Judarwanto (2011), kesulitan makan ditandai dengan perilaku memuntahkan makanan yang ada didalam mulut anak, makan dalam waktu lama, tidak mau memasukkan makanan kedalam mulut, membuang makanan dan menepis suapan dan (30,4\%) anak mengatakan tidak mau saat diberikan makanan. Anak usia 1-3 tahun dapat menyadari bahwa dirinya tidak sepenuhnya bergantung pada lingkungan sekitarnya, anak menuntut otonomi bagi dirinya seperti menolak waktu 
diberikan makanan.

Anak usia 1-3 tahun memiliki rasa ingin tahu yang tinggi dan mereka tertarik untuk memenuhi banyak hal dengan rasa ingin tahunya. Usia 1-3 tahun juga sibuk mengeksplorasi dunia disekitarnya. Menurut Wardlaw dan Hampl (2007), karena kesibukan mengeksplorasi lingkungannya terkadang mengalihkan anak dari makanannya. Selain itu anak juga memiliki rasa curiga jika disediakan makanan yang baru dikenalnya karena memiliki indra pengecap (papila) yang lebih sensitive dibandingkan dengan orang dewasa akibatnya hanya menyukai makanan tertentu yang berganti-ganti selama waktu tertentu (Sutardjo, 2011).

Orang tua yang memberikan makanan yang tidak sehat kepada anak seperti makanan yang banyak mengandung bahan pengawet yang sangat tidak baik bagi ktumbuh kembang anak tersebut dapat diganti dengan menggunakan garam pada makan anak sampai terasa gurih tujuannya agar anak dapat menyukai makanan tersebut, selain makanan yang memiliki rasa gurih sebaiknya orang tua juga menyediakan makanan yang manis agar anak tidak cepat bosen dengan makanan yang gurih, bisa menyediakan makanan manis dirumah. Pemberian makanan manis mendekati waktu makan dapat menyebabkan berkurangnya nafsu makan karena anak merasa sudah kenyang. Apabila sering menyediakan makanan manis juga dapat menyebabkan kebutuhan nutrisi anak tidak terpenuhi dengan baik dan anak menjadi ketagihan dengan makanan manis, sehingga lama-kelamaan akan menjadi kebiasaan dan mengakibatkan anak mengalami kesulitan makan. Anak usia 1-3 tahun mempunyai nutrisi yang adekuat untuk mempengaruhi kebutuhan fisiologis maupun kebutuhan pertumbuhan dan perkembangan. Orang tua khususnya ibu sangat mempunyai peran penting dalam penyediaan makanan di lingkungan rumah.

\section{Hubungan Modifikasi Penyajian Makanan} dengan Perubahan Nafsu Makan Anak Balita di Puskesmas Mojo Surabaya

Hasil uji statistik menunjukkan nilai $p=0,020$ $<\alpha=0,05$ yang membuktikan bahwa ada hubungan antara modifikasi penyajian makanan dengan perubahan nafsu makan anak balita di Puskesmas Mojo.

Balita di Puskesmas Mojo Surabaya menerima modifikasi penyajian makanan yang baik, dimana modifikasi penyajian makanan akan mempengaruhi pada nafsu makan, sehingga perubahan nafsu makan yang dialami oleh anak balita akan meningkat. Dengan dilakukannya modifikasi penyajian makanan yang lebih baik lagi dapat meningkatkan berat badan balita dan dapat mengurangi balita yang mengalami gizi buruk atau balita yang berada di bawah garis merah/BGM.

Modifikasi penyajian makanan perlu dimiliki oleh orang tua balita agar dapat terhindar atau meminimalkan terjadinya gizi buruk. Menurut penelitian Maharani (2009), modifikasi penyajian makanan yang baik berhubungan 
dengan perubahan nafsu makan anak balita yang cukup. Ada kaitan dengan peran ibu dalam mengatasi kesulitan makan pada balita, karena seorang ibu harus mengetahui berbagai hal yang terkait dengan perannya meliputi mengetahui makanan bergizi, jadwal makanan, cara mempersiapkan, cara menyajikan serta dalam mempersiapkan perlengkapan makannya. Seorang ibu harus mampu melatih makan pada anaknya dan sanggup mengantisipasi sewaktu anak susah makan (Winarsho, 2009).

Hasil penelitian di atas dapat membuktikan teori atau konsep yang menyatakan bahwa modifikasi penyajian makanan dapat mempengaruhi perubahan nafsu makan pada anak balita. Balita yang mengalami perubahan nafsu makan akan lebih senang menerima makanan yang sudah dilakukan moodifikasi, sehingga balita cenderung akan menghabiskan makanannya. Hal ini juga dapat dilihat dari faktor- faktor yang mempengaruhi asupan makan internal (Santoso, 2007) yaitu kebiasaan makan, rasa bosan, psikologis, penyakit. Faktor eksternal yaitu cita rasa, penampilan, jadwal makan, sikap orang tua, alat saji makan, lingkungan. Dengan adanya cara modifikasi penyajian makanan selera makan anak balita dapat meningkat dengan sendirinya sesuai yang dilakukannya menggunakan cara tersebut setiap hari. Orang tua juga dapat berkreasi sesuai dengan selera anak agar anak dapat terhindar dari kejadian gizi buruk atau di bawah garis merah/BGM. Selain itu, orang tua juga dapat mengetahui susunan makanan setiap hari yang sesuai dengan pola menu seimbang untuk dikonsumsi oleh anak balita agar dapat meminimalisir obesitas pada anak balita, serta orang tua dapat memberikan motivasi bagi anak agar anak dapat menikmati makanan tersebut dengan suasana yang menyenangkan, rasa makanan yang sesuai untuk balita, warna yang menggunakan warna alami apabila anak balita tersebut tidak menyukai sayur-sayur dan mengurangi menggunakan bahan-bahan yang mengandung pengawet.

\section{SIMPULAN}

Modifikasi penyajian makanan pada anak balita di Puskesmas Mojo Surabaya sebagian besar menerima dengan baik. Perubahan nafsu makan pada anak balita di Puskesmas Mojo Surabaya sebagian besar perubahan nafsu makan yang cukup. Ada hubungan antara modifikasi penyajian makanan dengan perubahan nafsu makan anak balita di Puskesmas Mojo Surabaya.

\section{DAFTAR PUSTAKA}

Almatsier. (2009) Prinsip Dasar Ilmu Giz̨. Jakarta: PT. Gramedia Pustaka Utama.

Ana Maria Choirunisa. (2009). Panduan Terpenting Merawat Bayi \& Balita. Jakarta. Cetakan I. Moncer.

Departemen Kesehatan. (2007). Pedoman Pemantauan Wilayah Setempat-GIZI (PWS- GIZI). Jakarta: Depkes RI.

Fathonah, S. (2005). Higiene dan Sanitasi Makanan. Semarang: UNNES Press. Guyton, A.C. and Hall, J.E., (2006). Textbook of Medical Physiology. 11th ed. Philadelphia, PA, USA: Elsevier Saunders. 
Hidayat, Aziz Alimul, (2010). Metode Penelitian Kesehatan; Paradigma Kuantitatif, Cetakan pertama. Surabaya : Health Books Publishing.

Irianto, K. dan Waluyo, K. (2006). Gizi dan Pola Hidup Sehat. Yrama Widya: Bandung.

Judarwanto, W. (2011). Mengatasi Kesulitan Makan pada Anak. Jakarta: Puspa Swara.

Moehyi. (2007). Ilmu Gizi. P.T. Bratara. Bandung.

Muaris.H. (2006). Sarapan Sehat Untuk. Anak Balita.

Jakarta : PT Gramedia Pustaka Utama.

Mukono, H.J. (2006). Prinsip Dasar Kesehatan Lingkungan. Surabaya: Airlangga University Press.

Neldawati. (2006). Hubungan Pola Pemberian Makan Pada Anak dan Karakteristik. Lain dengan Status Giri balita 6-59 Bulan di Laboratorium Gizi Masyarakat Puslitbang Giri dan Makanan (P3GM). Skripsi FKM UI.

Ngastiyah. (2007) Perawatan Anak Sakit. Jakarta: EGC.

Notoatmodjo. (2006). Metodologi Penelitian Kesehatan.

Jakarta: Rineka Cipta.

Nursalam. (2008). Konsep \& Penerapan Metodologi Penelitian Ilmu Keperawatan. Jakarta: Salemba Medika.

Ranuh. (2008). Pertumbuhan dan Perkembangan Anak. Jakarta: EGC.

Riskesdas. (2010). Riset Kesebatan Dasar (RISKESDAS) Tahun 2010. Jakarta.

Santoso. (2007). Kesehatan dan Giæi. Jakarta; Rineka Cipta.

Sediaoetama. (2008). Ilmu Giri Untuk Mabasiswa dan Profesi, jilid 1. Jakarta: Dian Rakyat.

Soegeng Santoso dan Anne Lies Ranti. (2006). Kesehatan Dan Giri. Jakarta: PT. Rineka Cipta.
Soehardi. (2006). Variasi Makanan Balita. Jakarta: PT Gramedia Pustaka Utama.

Soekirman, Prof. Dr. (2006) Hidup Sehat Giri Seimbang dalam Siklus Kebidupan Manusia. Jakarta: PT. Primamedia Pustaka.

Soetjiningsih. (2007). Tumbuh Kembang Anak. Jakarta : EGC.

Suhardjo (2007) Perencanaan Pangan dan Giz̨i.Jakarta: Bumi Aksara.

Supartini. (2007). Buku Ajar Konsep Dasar Keperawatan Anak. Jakarta: EGC.

Sutomo. B. dan Anggraeni. D.Y. (2010). Makanan Sehat Pendamping ASI. Jakarta: PT. Agromedia Pustaka.

Sutaradjo. (2011). Gizi Seimbang Dalam Daur Kebidupan. Jakarta: Gramedia Pustaka Utama.

Uripi. (2006). Menu Sehat Untuk Balita. Jakarta: Puspa Swara.

Wardlaw, G.M., \& Hampl, J.S. (2007). Perspectives in Nutrition ed. New york: Mc Graw Hill. 